\title{
Capacity of Local Institutions in Good Governance Implementation at the Local Context: The Case of Sleman Regency, Indonesia
}

\author{
Bagus Wahyu Hartono \\ School of Social Sciences, Faculty of Arts and Social Sciences, University of New South Wales, Sydney \\ (email: bagus.w.hartono@student.unsw.edu.au)
}

\begin{abstract}
The implementation of good governance at the village level is an essential element in shaping good governance at the district level. The practices that have been carried out at the village level are considered to be a reflection of what governance has originated from. In the midst of the implementation of decentralization policies, village communities are an integral part of the political dynamics in Indonesia. Villages with various local institutions have an essential role in managing local issues. In this research, data is mainly analyzed through a qualitative approach. Some quantitative analysis through scoring and descriptive statistical techniques are also conducted. Data collection methods are used as follows: documentation, observation, surveys with questionnaires, in-depth interviews, and Focus Group Discussion (FGD). This research identifies the Village Government has sufficient capacity to carry out its duties in village development. However, the realization of its capacity to solve local problems is still limited and only a partial solution. Weak coordination between institutions and limited budgets is the main problem found in study sites that hinders capacity realization in solving local problems. Furthermore, local government has made little effort to develop rural institutional capacity. So far, it only emphasizes capacity building for village officials, while other institutions only get little attention from the local government.
\end{abstract}

\section{Keywords:}

good governance; local institution; local government; local community

\section{Introduction}

The implementation of good governance at the village level is an essential element in shaping good governance at the district level. The practices that have been carried out at the village level are considered to be a reflection of what governance has originated from. Within the framework of village governance reform is undoubtedly relevant. According to Hastowiyono (2009: 3) there are several reasons, namely as follows: First, good governance is an institutional framework for strengthening village autonomy, because substantively decentralization and village autonomy is not just a matter of division of authority between levels of government, but as an effort to bring the state closer to the people. Good 
governance is the basis for implementing local autonomy at the village. Active and autonomous local government will not be meaningful and beneficial to local communities if it is not supported by transparency, accountability, responsiveness and community participation. Without good governance, local autonomy merely is moving centralization and many bad things from the central level to the local level. Second, the implementation of good governance at the village level is a solution to bad governance that has long been inherited from the New Order tradition (for example: centralistic and authoritarian, oligarchic, collutive, not transparent, and so on). Third, good governance is very relevant to express clearly between private and public affairs. In the village, between private and public affairs is very vague because it is framed with communalism. Fourth, the concept of good governance is very relevant to the rise of the spirit of democracy and the demands of the community for the implementation of village government that is more honest, clean, authoritative, free of $K K N$ (A notorious Indonesian acronym for corruption, collusion, and nepotism), responsible, and participatory. Fifth, the concept of good governance applied institutionally will be able to overcome the problem of managing power and government personally at the village level.

The notion of rural institutions that can solve their problems is very reasonable. Because when compared to outside parties, of course, rural communities and their institutions are already familiar with the problems and at the same time know the way to solve them. Based on the assumption, that capacity also lives in rural institutions, outsiders such as the government are expected not to interfere too much in rural communities. The government should facilitate local institutions by implementing empowerment, giving authority to make policies and provide the necessary financial and technical support (Rondinelli \& Cheema, 2007).

Several development programs have been implemented in many countries by prioritizing the role of local institutions. North in Nadeem (2016: 1) states that institutions are the rules of the game and the incentive structure of society. It is believed that economic growth and development depend on the quality of institutions fostered by the government. A study by Blair (2000) on community empowerment efforts by regional governments in Bolivia, Honduras, India, Mali, the Philippines and Ukraine found that community 
empowerment by local government leads to increased responsiveness and quality of public services.

In addition to success stories from the institutional approach, delegating the tasks of development to local institutions does not mean easy work. Many countries have experienced top-down development for quite a long time, one of which is in Indonesia, for example for more than three decades using the Musrenbang(Indonesian acronym for Musyawarah Perencanaan Pembangunan (Development Planning Meeting or Public Meeting)) forum so that local capacity may have been graded. Throughout the New Order village governments were in state co-optation and were not autonomous (Dwiyanto et al., 2003; Pramusinto \& Latief, 2012). In its report, UNDP (2002) states that weak institutions are one of the major problems in many developing countries, in addition to the other two problems, namely the training of thousands of people and lack of adequate skills.

When good governance is seen as an institutional framework based in rural communities, the substance of it is directly related to how relations between elements exist, including those involving actors in the village government, Village Parliament (BPD), the community and the private sector.

Furthermore, in looking at the perspective of the village government, the substance that can become the content includes policies made, finance, responsiveness, transparency, and accountability, all of which are linked to the dimensions of government, society, development and leadership. Whereas in looking at the perspective of the BPD as a political institution it is more associated with its representation, responsiveness, aspiration and accountability, all of which are directly related to its performance problems which refer to the main tasks and functions attached to it. In the aspect of society, in this case, it is associated with the problem of participation, both in terms of planning from below, understanding and involving themselves in the plurality of societies, citizen forums, control roles and so forth.

An understanding of the concept of good governance that is applied institutionally will be able to overcome the problem of managing power and government personally at the village level and assisting local government in developing patterns of relations with the community, especially in rural areas. Furthermore, this pattern can be used to formulate capacity building policies in community in the management of local governance. 
This paper has three main objectives, namely assessing the capacity of rural local institutions, understanding the implementation of capacity to solve local problems, and evaluating capacity building carried out by local governments. Furthermore, the organization of the paper as follows; discussion of local institutions covered in this study, findings that consist of embodiment of capacity, findings in capacity building carried out by the local government. It then draws conclusion and policy implication.

\section{Institutions in The Study}

Many local institutions in Indonesia, especially in Sleman, are inherited from the products of the New Order (1965-1998). At that time Indonesian politics needed a tool to be able to increase the efficiency of top-down planning through Law No. 5/1979 concerning Village Government. The village, which was once the smallest area as a community group that has autonomy experienced a process of corporatization by the state. As a result, the structure of the village government was made uniform and placed in the lowest hierarchy at the government level (Antlöv, 2000). Village management according to the Law places the village not as an autonomous unit, but the lowest government-controlled state through the subdistrict head (Pramusinto \& Latief, 2012). Government policies on villages have brought the village in a position of weak independence. Some institutions were formed in villages with the same structure, and these institutions were the only media to be able to voice the sound of development programs to the government. After the decentralization policy was implemented, the existence of these institutions still existed and almost without substantial changes. The most substantial change is the presence of the village parliament or BPD. Since decentralization is the distribution of tasks to several levels of government, the nature of the village as a form of a government institution is more prominent in formal legal regulations than in the form of community groups.

Many have agreed that the meaning of governance is pointing to one direction that the power or authority is no longer solely the business of government. The government was not exclusive in the realm of public policy (Ferlie, Lynn, Louise, \& Andrew, 1996; Osborne \& Gaebler, 1992; Osborne \& Plastrik, 1997; UNDP, 1997). The good governance framework when placed on the village scope, then there are two issues that need to be considered. First, the issue of democratic governance, which is the village governance originating "from" 
(community participation); managed "by" (accountability and transparency) the community; and utilized "for" (responsiveness) the community. Second, the relationship between elements of governance in the village based on the principle of partnership (alignment, balance and trust).

These two issues are like two sides of a coin that are different but cannot be separated. These two issues are like two sides of a coin that are different but cannot be separated. The value of the currency is the involvement of the community in the management of government and the development to achieve collective good. The pattern of relations between elements of governance can be equal and balanced if village governance is managed in a participatory, transparent, accountable, and responsive manner. Vice versa, democratic village governance (participatory, accountable, transparent and responsive) can be more robust, legitimate, and able to work effectively when supported by balance and trust between elements of governance in the village. In this case, the process of expanding public space is needed through lively and sustainable dialogues (citizen forums or village consultations).

To illustrate good governance, below is a map of governance at the village level. There are four elements of governance, namely 1) State (village government), 2) Political Society (BPD), 3) Civil Society (Community social organizations, local institutions, community members), and 4) Economic communities (arenas of production and distribution carried out by village economic actors and organizations).

Table 1.

Map of Governance at Village Level

\begin{tabular}{|l|l|l|l|}
\hline \multicolumn{1}{|c|}{ Element } & \multicolumn{1}{|c|}{ Actor } & \multicolumn{1}{c|}{ Arena } & \multicolumn{1}{c|}{$\begin{array}{c}\text { Governance } \\
\text { Relational Issue }\end{array}$} \\
\hline State & $\begin{array}{l}\text { Village Head and } \\
\text { Village Officers }\end{array}$ & $\begin{array}{l}\text { Regulation, control } \\
\text { of the community, } \\
\text { management of } \\
\text { policies, finance, } \\
\text { public services }\end{array}$ & $\begin{array}{l}\text { Accountability, } \\
\text { transparency, } \\
\text { responsiveness and } \\
\text { capacity }\end{array}$ \\
\hline Political Society & BPD & $\begin{array}{l}\text { Representation, } \\
\text { articulation, } \\
\text { aggregation, } \\
\text { formulation, } \\
\text { legislation, } \\
\text { socialization, control }\end{array}$ & $\begin{array}{l}\text { Capacity, } \\
\text { accountability, } \\
\text { responsiveness }\end{array}$ \\
\hline Civil Society & $\begin{array}{l}\text { Social Institution, } \\
\text { Social Organization, } \\
\text { Village People }\end{array}$ & $\begin{array}{l}\text { Self-reliance, } \\
\text { cooperation, mutual } \\
\text { cooperation, social }\end{array}$ & Participation (voice, \\
access and control)
\end{tabular}




\begin{tabular}{|l|l|l|l|}
\hline & & networks & \\
\hline $\begin{array}{l}\text { Economic } \\
\text { Community }\end{array}$ & $\begin{array}{l}\text { Economic Actors and } \\
\text { Organizations }\end{array}$ & $\begin{array}{l}\text { Production and } \\
\text { distribution }\end{array}$ & $\begin{array}{l}\text { Policy access, social } \\
\text { accountability }\end{array}$ \\
\hline
\end{tabular}

Source: Hastowiyono (2009)

The map illustrates that the state (village government) becomes the center of governance in the village, which has relations with the BPD, elements of civil society elements and the economic community.

The next subsection briefly describes the institution in each element related to the function capacity embedded in each institution.

\section{Village Government}

The elements of the village government consist of the Village Head, secretary, section head and hamlet head. The village head and hamlet head are directly elected by the community village. Village Secretary, Head of Section, Head of Affairs and Staff recruited from the village native and retire at 56 years old. With the political transition in Indonesia, the recruitment of Village Secretaries was carried out by appointing civil servants from the Sleman Local Government, and the staff recruitment uses the rules in accordance with Regional Regulation 16/2016 concerning Recruitment Village Officer. The Village Secretary, Head of Section, Head of Affairs and Staff routinely works in the village office and receives salary from their position. The salary of the Village Secretary comes from the APBD ${ }^{1}$, and the other comes from two sources, namely Bengkok land², and some additional allowances provided by the local government.

The village head is the personification of the village government (state). The village government empirically became a battleground between the state and the community. From the point of view of the state, the village government and the Village Head are links to the state bureaucracy, which carry out regulatory and control functions in the region and society through "administrative services", implementation of development projects, community mobilization to support government policies, service to the community to the interests of the state, withdrawing levies and others.

\footnotetext{
${ }^{1}$ Local Government Revenue and Expenditure Budget (Local Budget)

${ }^{2}$ A specific plot of land given to the village officer during his time of service.
} 


\section{Political Society}

Political society is a force and arena in democracy; it is related to political parties, political actors, representative institutions and elections. In a democratic setting is an arena where the community organizes itself to fight for legitimate rights to control public power and state apparatus. In the context of good governance requires the emergence of a democratic political society, which is able to become a bridge between the community and the state, based on civil society, able to exercise control over the state.

BPD is the most real and closest political community actor at the village level, which plays a role as a bridge between community elements and the village government (state). BPD is a new institution that was established after the decentralization policy in 2001. The main task of the BPD is to voice the aspirations of the people, oversee the running of the village government and make village regulations with the Village Head. The BPD is expected to play the role of articulating the interests of the people which are then brought and formulated into public policies at the village level. In the implementation of day-to-day governance and village development, the BPD has a normative role as a means of control of the village government. However, in the context of good governance, the partnership approach is more relevant than the confrontational approach, which enables parallels between the village government and the BPD. In addition, as a representative institution, the BPD is expected to be able to build legitimacy and accountability before the public, namely by maximizing the role of articulation, legislation and control. The political community that is centered on the BPD above certainly cannot be separated from civil society, which incidentally is the BPD base. In this context it can be interpreted as a civil society.

\section{Civil Society}

Civil society can be viewed from three ways, namely: First, civil society can be seen as an actor outside the state who plays a role in the process of social and political change. From the actor's point of view, civil society can be interpreted as grouping community members and social associations organized autonomously outside the influence of the state. It is different from "society" in general in that it involves citizens acting collectively to express their interests, desires, preferences and ideas, to exchange information, to achieve collective goals, to submit demands to the state, to improve state structure and function, and to demand accountability from state officials. Civil society is an intermediary phenomenon, 
standing between private and state spheres, so it does not involve local societies: individual and family life and inward group activities (recreation, entertainment, religious worship, spirituality); and does not include the economic community: business income from business/individual companies.

Second, civil society is seen as an arena (space and condition) that allows the growth of an autonomous society towards the state. As an arena, civil society also includes a process towards an ideal form of society. Hikam (1996) for example, defines civil society as areas of social life that are organized and characterized, among others: voluntary, self-generating, and self-supporting, independence in dealing with the state, and attachment with legal norms or values that are followed by its citizens.

Third, civil society is seen as an ideal goal to be achieved in the process of community empowerment. In this view, civil society is seen as a form of civilization that will be achieved through certain efforts. This civilized society is imagined in the form of a society that adheres to the law, ethics and rules and multiculturalism.

In the classical literature of political science, civil society as an idea is known as a democratic culture. In Indonesia, this third meaning is more popular with civil society. In The Encyclopedia of Democracy (1995), it mentions several fundamental characteristics of civil society. First, civil society is autonomous (independent) from the state. At least, it bridges between citizens and the state. Civil society is a public arena that is able to manage activities and organize its members independently. This character manifests in local organizations that grow and develop in society, whether based on religion, occupation, hobbies, or certain cultural communities. Besides that, the manifestation of this selfgoverning community is more or less supported by the strong enough social capital (norms, traditions, social networks, and other local values) that develop in the village community. Second, civil society has a character as access for the community to the country. In other words, civil society, one of which manifests itself in the form of social organization, is the basis of community participation in the practice of everyday village governance. In civil society, it is discussed about voluntary and non-profit social organizations.

In this study, the civil society groups in the village are village-based social groups such as Neighborhood Groups, Family Welfare Program, and Village Development Committee. 


\section{Economic Community}

The economic community is the discourse of the private sector (economic actors) who seek profits through production and distribution. The market is the closest and real arena for the economic community to exchange and seek profits. Good governance promotes economic democratization, a healthy competitive market and good corporate governance as the ideal characteristic of the economic community.

In the village context, the main concern is located on the basis of the "people's economy", especially the actors and economic organizations of the people in the context of their relations with markets, sources of capital and village government. The focus is on opportunities and the ability to access village economic actors and organizations towards the capital resources provided by the state, access to village government policies, access to markets. Elements of the economic community need to be organized into a force to build their participation in the context of village policy in the productive economic sector. On the other hand, it also encourages village governments to be more responsive to the empowerment of village economic organizations so that people's economic potential develops better. In this study, the economic community groups in the village are Local Entrepreneurs/ Small and Medium Enterprises (SMEs).

\section{Relations between Elements}

The relationship of the four elements interacts dynamically (can stretch or close) according to the strength and bargaining position possessed by each institution (Figure 1). In a village area and a particular time, it is possible for an institution to be more dominant than other institutions in social interaction. For example in the period of Law 5/1979 concerning Village Government in the New Order era, the Village Government was more dominant than political institutions, economic communities, and civil society.

The ideal relationship in life at the village level is that these four elements are involved in the process of governance and village development. In other words, it is necessary to build comprehensive participation and strengthen each other between the institutions in the village. In academic language, mutually reinforcing relationships are known as good governance. 
Good governance in this context is an agreement about the administration of a government which is created jointly by all elements in a region. If at the village level, good governance is an agreement on the implementation of village governance jointly created by the village government, political institutions (BPD), economic institutions, and social institutions. In other words, Good Village Governance refers to the process of creating cooperative relations between the four institutions in the village to make arrangements that are used in the administration of village governance.

Figure 1.

Ideal Relationship of the Four Elements of the Village

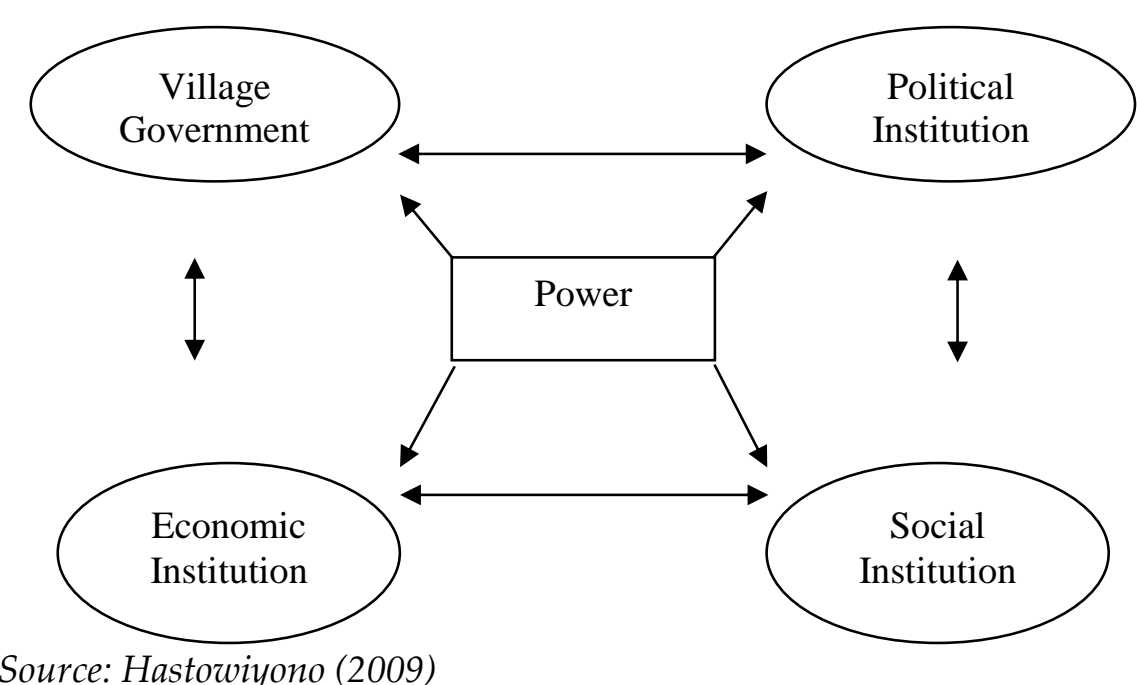

\section{Data and Methods}

Data was mainly analysed through a qualitative approach. This study involved one main research period to collect primary data in early 2018. Data collection methods are used as follows: documentation, observation, surveys with questionnaires, in-depth interviews, and Focus Group Discussion (FGD). Research participants were recruited from various professional backgrounds at three levels: local government, the business sector, and civil society.

Participants from the local government were drawn from two levels. First, at the district level, participants were officials selected in order to obtain information on how they conceive the policy of good governance practices from concept to implementation in Sleman Local Government. They included Bupati (Regent), senior members of DPRD (local parliament), high-ranked officials in the executive branches such as Head of Development 
Planning Agency, Head of Governance Department, and Camat (Head of Subdistricts) in the four different areas of Ngaglik, Gamping, Cangkringan, and Prambanan. Second, at the village level, participants were selected from key actors in the implementation of local development, including village heads, village officers, members of Badan Permusyawaratan Desa/BPD (village parliament), and hamlet heads.

Four sub-districts were chosen to represent urban and rural areas with two villages as part of the study sites, namely Gamping and Ngaglik for urban areas and Prambanan and Cangkringan for rural areas. Since the decentralization policy is emphasized at the subprovincial or district level of local government, the research examines the local realities where it is implemented.

Participants from the business sector were recruited from local entrepreneurs Usaha Kecil dan Menengah/SMEs. Those from civil society are experts from universities, nongovernmental organizations, and village-based social groups such as Rukun Tetangga/Warga (Neighbourhood Groups), Pembinaan Kesejahteraan Keluarga/PKK (Family Welfare Program), and Lembaga Pemberdayaan Masyarakat Desa/LPMD (Village Development Committee). Participants from the business sector and civil society were selected to explore perception and understanding in society regarding the implementation of good governance practices by the local government.

The study only selected participants who had resided in Sleman Regency for at least five to ten years. The purpose of this criterion was to prevent judgment-bias from any respondents who had only resided a short time in the region. In order to secure privacy, all research participants are not individually identifiable in the study, and no names were used during the data collection and analysis, or in the dissemination of the study. Dates of birth were noted only to avoid duplication, for example, if the data were collected over a period of time and the participants had moved from one position to another. Specific dates of birth are not used in the published and disseminated results. All participants were noted according to their affiliation and expertise, for example, Head of Development Planning Agency, Sleman Local Government, or Balecatur Village Development Community, Gamping Sub-district.

The research purposively selected Sleman regency because prior to enactment of decentralization policy in 2001 under the Law 22/1999 on Local Government, Sleman was chosen as a pilot project of the regional autonomy program within the Special Province of 
Yogyakarta in 1995. This model of autonomy has enabled Sleman to step forward in adopting the new decentralization policy compared to other districts, especially in Yogyakarta Special Province. This model was intended to serve as a limited decentralization policy, and therefore Sleman has been able to focus on the new the Law 22/1999 on Local Government in responding to the new setting.

\section{Results}

\section{Embodiment of Capacity}

Following subsections explain the evidence about how the capacity is manifested to answer local problems. There are two problems identified in this study, namely general problems and specific problems. The fundamental problem faced by villages in the same sub-district is the limited funding to carry out development. This limitation is a barrier to the smooth running of community mobilization due to the limited physical infrastructure such as drainage channels and public roads. For specific problems generally related to the socio-economic conditions of each village in the sub-district. Urban sub-districts such as Ngaglik and Gamping sub-districts experience problems related to increasing population

density and poverty. For rural sub-districts in Prambanan and Cangkringan, they have problems related to the development of productive economies.

\section{Case of Ngaglik Subdistrict}

Ngaglik Subdistrict is one of the areas included in urban areas in Sleman Regency. With a population of 99,255 people, Ngaglik Subdistrict has a population density of 25,765 people $/ \mathrm{km}^{2}$ (BPS Sleman, 2017). In running the government in Ngaglik Subdistrict, the Head of Subdistrict (Camat) regularly holds a Government Coordination Meeting every month. He said that the subdistrict was included in the urban sphere and continued to try to include all rural institutions in the implementation of development in the village. Given that the types of subdistrict is relatively urban, meeting schedules are made flexible so that they can accommodate the needs of all parties. Although it was acknowledged that sometimes not many participants attended the meeting, because of the private business in urban communities (Interview with Camat Ngaglik, 18 January 2018). Another phenomenon can also be found in participant observation when attending the District Musrenbang on January 25, 2018. It shows that only a few people attended the meeting. 
Relatively problematic resource mobilization. In addition, in the Village of Sardonoharjo, the Village Head, BPD and other institutions found it difficult to make consensus. For example, prioritizing development activities requires a long discussion. Coordination of village government activities did not go well due to the leadership style of the village head, which tended to be weak. The FGD participants considered that the leadership of the Village Head was not very popular in the eyes of the community, which was dominated by urban and educated people ${ }^{3}$. This leadership style that tends to be weak can be possible because the village head has held his position for two periods. With his final term of service, the Village Head feels that there is nothing to worry about his position politically. The problem in the inter-institutional relations has influenced the possibility of the success of Sardonoharjo Village in resolving their local problems.

\section{Case of Gamping Subdistrict}

Compared to Ngaglik Subdistrict, the area of Gamping Subdistrict is much larger, which is $29.25 \mathrm{~km}^{2}$, so the problem faced is far more far-reaching. In contrast to the flexible Ngaglik Subdistrict meeting schedule, in Gamping Subdistrict, the Governance Coordination Meeting is scheduled on the 17th of each month. To answer the limited budget in this region, the Village Heads made several breakthroughs in establishing networking with several local entrepreneurs in the region. According to Camat Gamping, the Village Heads realized that the government budget allocated for development in the region would never be sufficient to build up the physical infrastructure of the drainage channel in particular4. By networking with local entrepreneurs, it is believed that they have a great opportunity in obtaining funds rather than waiting for funds from the local government. Other institutions such as BPD, LPMD, and SMEs also agree with the steps taken by the village head. Some of the priority drainage channels that are urgent to be built include 1) Ngawen Street to Kenteng Fish Market, 2) Ngawen Street to Kenteng (Mayangan), and 3) Ngaran Street to Rewulu, with total funds needed of IDR245 million.

In fact, some FGD discussion participants stated that the village head, especially Balecatur Villlage, sometimes did not hesitate to issue personal funds for development

\footnotetext{
${ }^{3}$ FGD 22 January 2018.

${ }^{4}$ Interview with Camat Gamping, 19 January 2018.
} 
purposes in her area, given the urgency of flood resolution to be very high in the region ${ }^{5}$. So in 2018 had they waited for assistance from the local government, the fund might have taken even longer. With the combination of the popularity of the village heads and the smooth running of political communication, the village heads can quickly mobilized resources in their respective areas.

\section{Case of Prambanan Subdistrict}

Prambanan subdistrict is categorized in a rural area. It is located far east of Sleman Regency bordering the Central Java Province. In order to overcome the limitations of funds, the strategy agreed upon in the routine monthly agenda in the Governance Coordination Meeting was the village head building networking with several Local Parliament (DPRD) members from this region. By entrusting the proposal to the DPRD members, they believe funding from the local government will be more comfortable than the village head himself who proposes to the local government ${ }^{6}$.

In rural communities, the authority of a community leader is still very evident, such as the Village Head and Hamlet Head. Both in Gayamharjo and Wukirharjo Villages, almost all decision making involved a perspective from the rural leaders. The BPD as the village government partner sometimes does not have the power to control the running of the government, because rural communities generally entrust their voice to the village head. The strong legitimacy of the leadership of the village head is a very dominant factor in village governance.

\section{Case of Cangkringan Subdistrict}

Village institutions in Cangkringan Subdistrict showed an optimal role compared to other subdistricts in this study in managing the dynamics of their people's lives. This situation is because the area routinely experiences the effects of the disaster of the Mount Merapi eruption. The implementation of routine meetings with all institutions, both from the elements of the Village Head, BPD, Community Organizations, and SMEs, brings benefits in bridging communication with outside parties. A lot of assistance granted from the central government, local governments, and donors from the private sector that

\footnotetext{
${ }^{5}$ FGD 25 January 2018. Village Head Balecatur happens to be the wife of the leader of Islamic Community Organization in the Central Java and Yogyakarta region. One of her daughters is a member of Sleman Local Parliament from Gerindra political party.

${ }^{6}$ Interview with Camat Prambanan, 18 January 2018.
} 
provided assistance in handling the impact of the last erupting volcanic disaster in late October 2010. The leadership of the village head in managing governance is still very strong by opening networking from outside the subdistrict. The physical recovery process of victims of the Mount Merapi eruption is relatively fast because of the social capital that is still strong and reliable. Solidarity from various institutions between villages and at the regional, national and even international levels is able to become a driver for the reconstruction process $^{7}$.

The occurrence of this disaster became a blessing in disguise phenomenon. The eruption of Mount Merapi has devastated the economic sectors of the middle to lower classes. For example, the dairy farming sector, broiler and goat experienced a severe level of damage. With the existence of government and private assistance, it can be a quite effective driving force in the recovery process. This sector is a mainstay in the economic development of the community after the impact of the eruption.

\section{Capacity Development from Local Government}

The study of documentation in the Annual Report shows that the Local Government has allocated programs to develop capacity for village government apparatus in 86 villages in the form of training every year. In 2018, the Sleman Regency Government budgeted IDR 13,250,937,100 in eight programs (Sleman Local Government, 2018).

This is also reinforced by the statement of the Sleman Regent:

Now the demands of the community to be involved in various processes of village governance, especially in relation to village development, are getting stronger. Not only that, the people's demand for transparency and accountability in the implementation of village governance (both regarding policies and public services and village financial / wealth management) also strengthened. Therefore, good village governance needs to be strengthened. For this reason, commitment, initiative, creativity, the spirit of togetherness / partnership of various elements are needed. No less important than all that, is the existence of transformative and facilitative leadership ${ }^{8}$.

In line with the Sleman Regent, the Deputy Chairperson of the DPRD also explained the importance of Good Governance at the village level. Village good governance will work

\footnotetext{
${ }^{7}$ Interview with Camat Cangkringan 19 January 2018.

${ }^{8}$ Interview with Sleman Regent 18 January 2018.
} 
better if the village is led by people who have adequate capacity, creative and innovative, as well as facilitative ${ }^{9}$.

The training program was given in the form of socialization of new regulations, preparation of village implementation reports, preparation of Medium Term Development Plan (RPJM Desa), drafting of village budgets, and archival affairs. To strengthen the sustainable village planning system, the central government through the local government has implemented the Village Profile program to LPMD accompanied by software for operator training. Capacity building for village community institutions is carried out in 200 Lower Neighbourhood Head (RTs) and 160 Upper Neighbourhood Heads (RWs) in three subdistricts. Whereas BPD is carried out through facilitating BPD forum meetings six times. In addition to the training program in the administration aspect, technical training that addresses daily problems is still very limited. For example, entrepreneurship training and waste management for rural institutions are still very rare.

From the explanation above and also the statement from the Sleman Regent and the Deputy Chairperson of the DPRD, it can be seen that the local government only focuses on developing the capacity of village officials, especially the village heads. BPD and other institutions were still neglected. Although the previous section shows that the BPD, LPMD, and other institutions have the capacity to carry out their functions, the existence of their competencies is not the result of capacity building by the local government. But it is the result of the learning process itself.

\section{Discussion}

In the previous section, the paper presented about the capacity of several rural institutions and their realization in overcoming local problems. The findings of this study are generally in line with what Bebbington (1999) said, that good capacity does not always produce good performance due to complex sociocultural factors in determining capacity realization.

The case of four subdistricts in Sleman Regency suggested that the possibility of success in answering local issues was very significantly influenced by the leadership of the village head. So leadership capacity is indeed very influential. The village head gives the

\footnotetext{
${ }^{9}$ Interview with Vice Chairman of Local Parliament, 18 January 2018.
} 
impression that governance at the village level is still dominated by the state. Relations between the village head, BPD and other institutions still do not work as intended in the village structure. The village head is still too strong and dominates the village governance.

The formation of the BPD after the 2001 decentralization policy still cannot make the power map more balanced. The BPD positions itself far from a work partner, Village Social Groups such as LPMD, RT/RW tend to be subordinates of the village head. Good governance expects that elements in the village can carry out their duties and work together in village governance without any cultural obstacles so that the domination of the village head to some extent prevents success in solving local problems.

The general problem above is very interesting to observe with regard to the relationship between power and local culture. Throughout the New Order the village government was not in an autonomous position. The position and existence of the village government do not have adequate autonomy, because it is controlled centrally and hierarchically with supra village government regulations. Consequently, the village government (read the Village Head) has legal and political accountability to the supra village government.

In the decentralization system, villages are given a more extensive space through reforming structures where control is in the hands of the community. Given that in Javanese local culture in seeing the figure of the village head as a respected person, the village governance in the decentralization policy has not changed much from the previous traditional pattern. The village head, assisted by several village officials, still dominates village politics and prevents other institutions such as BPD, LPMD, RT/RW, SMEs from performing their roles, both overseeing the village head, in consultation with the village head, and demanding the same position in local governance.

Of course, this is not merely a matter of culture. Local governments also contribute no less critical in the form of resources and support. Among all the institutions in the village, only the village head and village officials receive a regular salary and work facilities in an organization. Whereas other institutions are only voluntary work and are not given an adequate salary. So that it becomes challenging to expect total devotion from them. Even if there are incentives from the local government, the amount is not much. Support in the form of capacity building is often only given to the village head and their staffs. The village head 
is the only institution legally accepted to represent the village in the presence of outsiders, especially the local government. So, village head is essential because it can develop networks with outside parties. He has the best capacity among all rural institutions, eliminates the BPD, and other institutions that struggle for themselves to understand the complex issues of decentralization.

\section{Conclusion and Policy Implication}

The village government has sufficient capacity to carry out its duties in village development. However, the realization of its capacity to solve local problems is still limited and only a partial solution. Weak coordination between institutions and limited budgets is the main problem found in study sites that hinders capacity realization in solving local problems. Furthermore, local government has made little effort to develop rural institutional capacity. So far, it only emphasizes capacity building for village officials, while other institutions only get little attention from the local government.

Efforts such as capacity building are needed for other institutions. The most urgent is the capacity building of the BPD that can be done by strengthening the personal capacity of BPD members, strengthening institutional capacity of the BPD, through training, courses and other educational media.

Strengthening civil society can also be done by strengthening the bargaining position of civil society towards the Village Government, especially in the process of organizing village public policies. The steps that can be taken are increasing civic education, political awareness and improving the quality of existing community forums in the village as an arena for citizens to find problems and solutions.

With regard to the economic community, to strengthen village economic actors, the Village Government must open access for them to voice their aspirations regarding their activities. The emergence of economic groups such as farmer groups, livestock, craftsmen and home industries, can be used as a vehicle to strengthen bargaining positions against the Village Government and economic actors outside the village. In addition, increasing the budget transfer from district to the village is also important, so that the village government has sufficient budget to solve village problems. 


\section{References}

Antlöv, H. (2000). Village governance in Indonesia: past, present and future challenges. In PERCIK Conference "Dynamics of Local Politics in Indonesia," Yogyakarta.

Bebbington, A. (1999). Capitals and capabilities: A framework for analyzing peasant viability, rural livelihoods, and poverty. World Development, 27(12), 2021-2044. Retrieved from http://search.proquest.com/docview/229562353/

Blair, H. (2000). Participation and accountability at the periphery: Democratic local governance in six countries. World Development, 28(1), 21-39. https://doi.org/10.1016/S0305-750X(99)00109-6

BPS Sleman. (2017). Sleman Regency in Figure. Sleman.

Dwiyanto, A., Arfani, R. N., Hadna, A. H., Kusumasari, B., Maika, A., Nuh, M., ... Yusuf, M. (2003). Reformasi Tata Pemerintahan dan Otonomi Daerah (I). Yogyakarta: Center for Population and Policy Studies UGM.

Ferlie, E., Lynn, A., Louise, F., \& Andrew, P. (1996). The New Public Management in Action. $\begin{array}{llll}\text { Oxford: } & \text { Oxford } & \text { University }\end{array}$ https://doi.org/10.1093/acprof:oso/9780198289029.003.0001

Hastowiyono. (2009). Implementasi Good Governance di Tingkat Desa. Yogyakarta: Unpublished paper.

Hikam, M. A. (1996). Demokrasi dan civil society / Muhammad A.S. Hikam; pengantar, Franz Magnis-Suseno. Jakarta: LP3ES.

Nadeem, M. (2016). Analyzing Good Governance and Decentralization in Developing Countries. Journal of Political Sciences $\mathcal{E}$ Public Affairs, 4(3), 1-8. https://doi.org/10.4172/2332-

Osborne, D., \& Gaebler, T. (1992). Reinventing Government: How the Enterpreneurial Spirit is Transforming the Public Sector. New York: N.Y. Plume.

Osborne, D., \& Plastrik, P. (1997). Banishing Bureaucracy: The Five Strategies for Reinventing Government. Massachusetts: Addison-Wesley.

Pramusinto, A., \& Latief, M. S. (2012). Dinamika Good Governance di Tingkat Desa. JIANA ( Jurnal Ilmu Administrasi Negara ), 11(01), 489-498.

Rondinelli, D. A., \& Cheema, G. S. (2007). Decentralizing Governance, Emerging Concepts and Practices. In D. A. Rondinelli \& G. S. Cheema (Eds.), From Government 
Decentralization to Decentralized Governance (pp. 1-20). Washington DC: Brookings Institution Press.

Sleman Local Government. (2018). Annual Accountability Report.

The encyclopedia of democracy. (1995). Washington, D.C.: Congressional Quarterly.

UNDP. (1997). Tata Pemerintahan yang Baik dari Kita untuk Kita (Good Governance by us for us). Jakarta: UNDP.

UNDP. (2002). Capacity for development: new solutions to old problems. Sterling, VA: Earthscan Publications. 